\title{
DNA repair-related functional assays for the classification of BRCA1 and BRCA2 variants: a critical review and needs assessment
}

\author{
Amanda Ewart Toland, ${ }^{1}$ Paul R Andreassen ${ }^{2,3}$
}

${ }^{1}$ Department of Cancer Biology \& Genetics and Division of Human Genetics, Department of Internal Medicine, Comprehensive Cancer Center, The Ohio State University, Columbus, Ohio, USA ${ }^{2}$ Division of Experimental Hematology and Cancer Biology, Cincinnati Children's Research Foundation, Cincinnati, Ohio, USA

${ }^{3}$ Department of Pediatrics, University of Cincinnati College of Medicine, Cincinnati, Ohio, USA

\section{Correspondence to} Dr Amanda Ewart Toland, Division of Human Genetics, Department of Internal Medicine, The Ohio State University, Columbus, Ohio 43210, USA; Amanda.toland@ osumc.edu and Dr Paul R Andreassen, Division of Experimental Hematology and Cancer Biology, Cincinnati Children's Research Foundation, Cincinnati, Ohio 45229, USA; Paul.Andreassen@cchmc.org

Received 29 March 2017 Revised 4 June 2017 Accepted 27 June 2017 Published Online First 2 September 2017

\section{CrossMark}

To cite: Toland AE,

Andreassen PR. J Med Genet 2017:54:721-731.

\section{ABSTRACT}

Mutation of BRCA1 and BRCA2 is the most common cause of inherited breast and ovarian cancer. Genetic screens to detect carriers of variants can aid in cancer prevention by identifying individuals with a greater cancer risk and can potentially be used to predict the responsiveness of tumours to therapy. Frequently, classification cannot be performed based on traditional approaches such as segregation analyses, including for many missense variants, which are therefore referred to as variants of uncertain significance (VUS). Functional assays provide an important alternative for classification of BRCA1 and BRCA2 VUS. As reviewed here, both of these tumour suppressors promote the maintenance of genome stability via homologous recombination. Thus, related assays may be particularly relevant to cancer risk. Progress in implementing functional assays to assess missense variants of BRCA1 and BRCA2 is considered here, along with current limitations and the path to more impactful assay systems. While functional assays have been developed to independently evaluate BRCA1 and BRCA2 VUS, high-throughput assays with sufficient sensitivity to characterise the large number of identified variants are lacking. Additionally, because of relatively low conservation of certain domains of BRCA1, and of $B R C A 2$, between humans and rodents, heterologous expression in rodent cells may have limited reliability or capacity to assess variants present throughout either protein. Moving forward, it will be important to perform assays in human cell lines with relevance to particular tumour types, and to strengthen risk predictions based on multifactorial statistical analyses that also include available data on cosegregation and tumour pathology.

\section{BRCA1 AND BRCA2 AS CANCER GENES}

In the 1990s, pathogenic variants in BRCA1 and $B R C A 2$ were found to be associated with hereditary breast and ovarian cancer (HBOC). ${ }^{12}$ Among genes associated with HBOC, BRCA1 and BRCA2 confer the highest lifetime risks of these cancers and are the most frequently mutated genes in women with HBOC. ${ }^{3-6}$ Other cancers also show elevated incidence of mutations in BRCA1 (melanoma and testicular) and BRCA2 (male breast cancer, prostate cancer and pancreatic cancer). ${ }^{7}$

\section{CLINICAL BENEFITS OF GENETIC TESTING FOR BRCA1 AND BRCA2}

Genetic testing for pathogenic variants in BRCA1, $B R C A 2$ and other cancer susceptibility genes is recommended for individuals with a strong family and/or personal history of HBOC (see figure 1), since risk preventative strategies improve outcomes. Indeed, individuals who carry a pathogenic variant in BRCA1 and BRCA2 are recommended to consider prophylactic surgeries including bilateral risk-reducing mastectomy (RRM) and/or risk-reducing bilateral salpingo-oophorectomy (rrBSO). Individuals undergoing RRM are thought to reduce their risk of breast cancer by $85 \%-100 \% .{ }^{8}$ Ovarian cancer risk is estimated to decrease by $69 \%-100 \%$ in BRCA1 carriers and BRCA2 carriers who undergo rrBSO. ${ }^{89}$ Importantly, screening for ovarian cancer is not as efficacious as for breast cancer. Therefore, since individuals with ovarian cancer are more likely to be diagnosed at later stages, rrBSOs are strongly suggested for BRCA1 and BRCA2 mutation carriers at age $35-40$ or when childbearing is complete. ${ }^{10}$ Additionally, rrBSOs also lead to a decreased risk of breast cancer in women with pathogenic BRCA variants. $^{8}$

Knowledge of BRCA1 and BRCA2 pathogenic mutations also helps to guide cancer treatment. Tumours with loss of functional BRCA1 and/or BRCA2 are responsive to chemotherapeutic agents that induce DNA damage, such as cisplatin. ${ }^{11-14}$ More recently, the US Food and Drug Administration has approved the poly(ADP-ribose) polymerase (PARP) inhibitors, olaparib and rucaparib, for treating certain individuals with advanced ovarian cancer whose tumours have either germline or somatic mutations in BRCA1 or BRCA2. ${ }^{15-17}$ PARP inhibitors appear to be particularly efficacious in tumours that have suppression of DNA repair due to defects in the homologous recombination (HR) pathway, such as tumours lacking functional BRCA1 or BRCA2. ${ }^{18}$ Given the efficacy of PARP inhibitors, the current recommendations are that individuals with ovarian cancer have BRCA1/2 germline and/or tumour testing in order to direct therapy. As these recommendations are being incorporated into clinical care, the number of individuals having germline and/or somatic genetic testing for these genes is increasing.

\section{CHANGES IN THE LANDSCAPE OF TESTING OF BRCA1 AND BRCA2}

The landscape of genetic testing for BRCA1 and $B R C A 2$, and other cancer susceptibility genes, is changing. For example, there are calls by some experts for doing population-based screening of the 


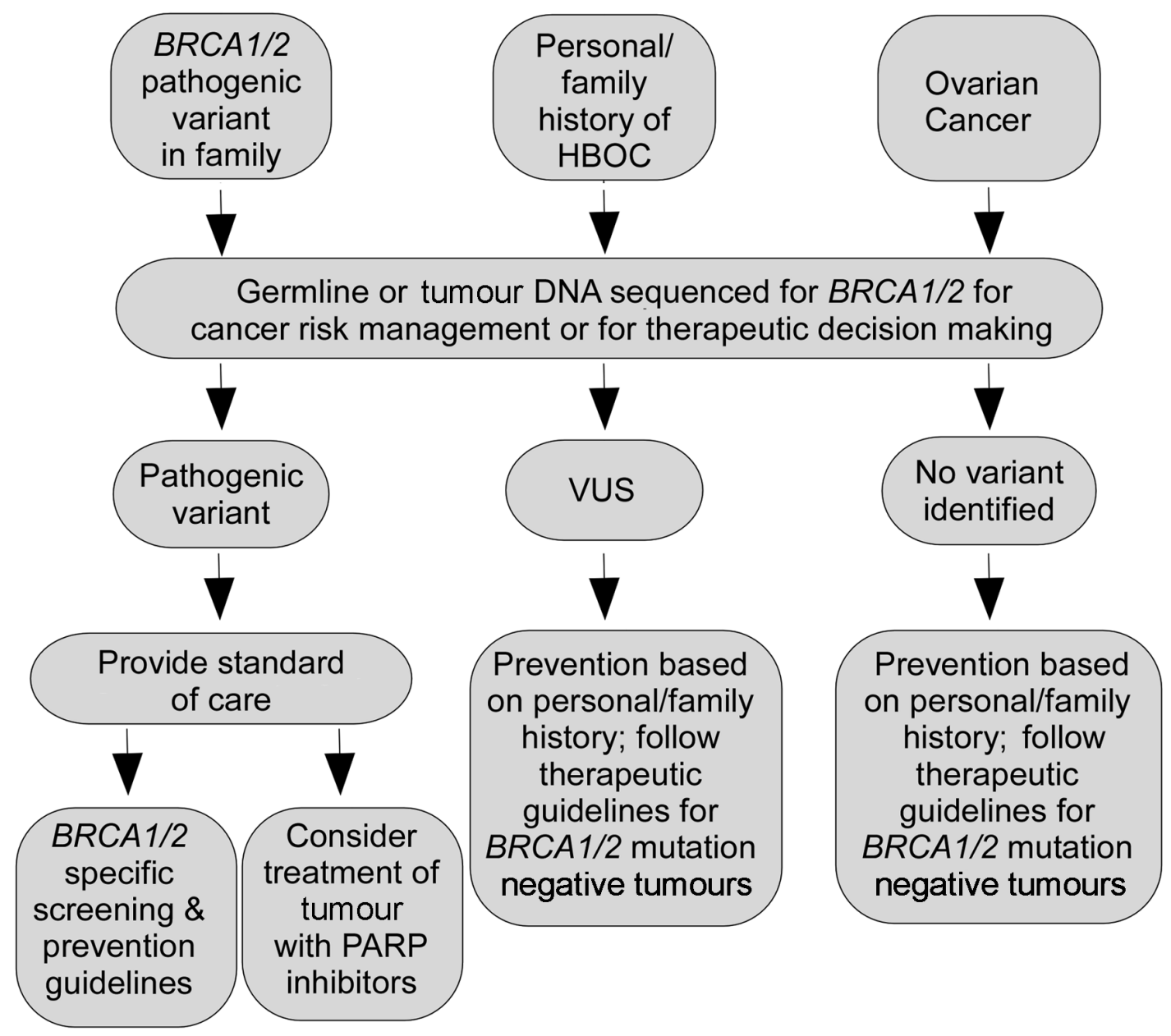

Figure 1 Decision-making tree for when to sequence $B R C A 1 / 2$ and for utilisation of the results. The decision-making tree for prevention and/or treatment recommendations is outlined for three scenarios in which clinical testing for BRCA1/2 is routinely done. HBOC, hereditary breast and ovarian cancer; PARP, poly(ADP-ribose) polymerase; VUS, variants of uncertain significance.

BRCA1 and BRCA2 genes of all women of a certain young age in order to prevent these cancers from occurring. ${ }^{19}$ Multiple factors underlie the current landscape of genetic testing. These include increased awareness of these genes by the public, changes in patent laws for BRCA1 and BRCA2, technological changes enabling the testing of multiple genes at cheaper costs, and testing of tumour DNA to identify either germline or somatic changes as a means to guide therapy. In particular, in June 2013, after hearing the case of the Association for Molecular Pathology $v$ Myriad Genetics, Inc, the Supreme Court of the United States ruled that genes, which occur naturally, cannot be patented. This has led to multiple clinical molecular laboratories in the USA offering genetic testing for BRCA genes. Notably, competition in the market-place has helped make testing more affordable. Collectively, these events have led to increased rates of individuals being tested for mutations in BRCA1 and BRCA2, ${ }^{20}$ and an increased need for interpreting the significance of variants that are identified.

The major challenge associated with the vastly increased numbers of individuals who are having testing for BRCA1 and $B R C A 2$ is that variants of uncertain significance (VUS) remain an issue. VUS, mainly missense alterations, are variants of unknown clinical impact; thus, individuals who carry a BRCA1/2 VUS do not have concrete information on which to make clinical decisions about cancer risk management or treatment. The effects of VUS on clinical decision-making, based on the results of genetic screens, are summarised in figure 1. This review will focus on DNA repair-related approaches to classifying variants, the pros and cons of the use of such functional assays for classification of BRCA1/2 variants and suggestions on how to move this field forward. In contrast to other reviews on the functional classification of BRCA1/2 variants, ${ }^{21} 22$ our up-to-date examination of the subject highlights the limited homology of rodent and human BRCA1 and BRCA2. As a result, we discuss the clear need to perform assays in human cells to enable the assessment of variants present anywhere within either protein.

\section{PREVALENCE OF GERMLINE AND SOMATIC VUS OF BRCA1 AND BRCA2}

There are multiple databases including the Breast Information Core, ClinVar, Leiden Open Variation Database (LOVD) and the Global Alliance that catalogue germline genetic variants in $B R C A 1$ and BRCA2 found through clinical sequencing. In particular, ClinVar is a database supported by the National Center for Biotechnology Information that annotates the clinical significance of human DNA sequence variants, as defined by the testing laboratory, locus-specific databases and/or an expert panel. ${ }^{23}$

Given that both BRCA1 and BRCA2 have key domains at or near their C-termini (figure 2A,B), nearly all nonsense and frameshift mutations result in truncations that can be classified as deleterious. The exception to this is variants in the last exon of 

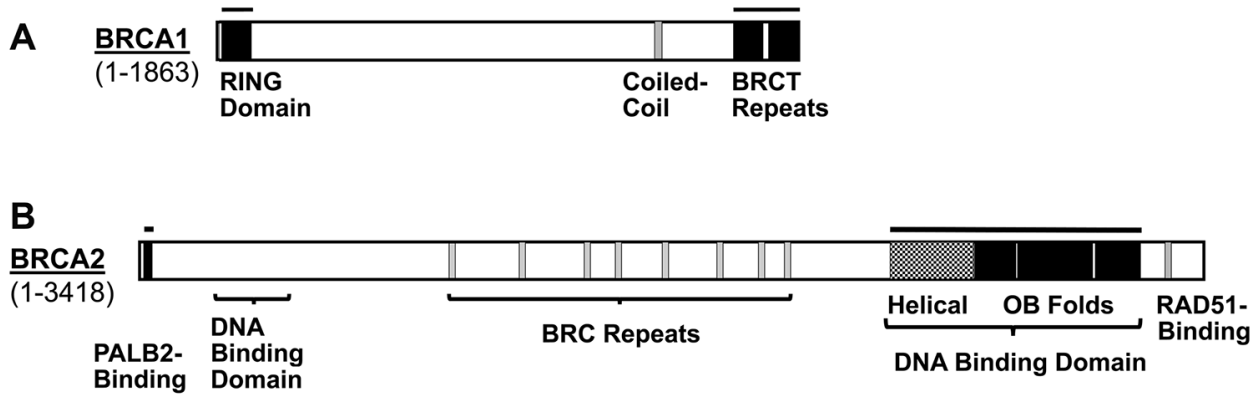

Figure 2 A diagram of key structural domains of BRCA1 and BRCA2, all of which are involved in mediating DNA repair by homologous recombination, reflects the role of each protein. (A) Human BRCA1 has a RING domain from amino acids (a.a.) 9-98, a coiled-coil domain at a.a. 1393-1424 and two BRCT (BRCA1 C terminus) repeats (a.a. 1649-1734 and a.a. 1758-1859). Nuclear localisation signals (NLS) at a.a. 503-508 and 607-615 are not shown due to their small sizes. (B) BRCA2 contains a PALB2-binding domain (а.а. 10-40), and a RAD51-binding domain from a.a. 1008-2082 that includes 8 BRC repeats (grey bars) and intervening sequence (BRC1: a.a. 1008-1033, BRC2: 1218-1243, BRC3: 1427-1452, BRC4: 1523-1548, BRC5: 1670-1695, BRC6: 1843-1868, BRC7: 1977-2002 and BRC8: 2057-2082). BRCA2 also contains a DNA-binding domain (DBD) from a.a. 2402-3102, which is composed of a helical domain (a.a. 2402-2669) and three OB (oligonucleotide/oligosaccharide) folds (a.a. 2670-2803, 2809-3048 and 3056-3102), and a second RAD51-binding domain at the C-terminus (a.a. 3270-3305). Another DBD, which is less well defined than the C-terminal DBD, is present in BRCA2 within the region between a.a. 250 and 500. Two NLS at a.a. 3263-3269 and 3381-3385 are not shown. In both (A) and (B), domains that contain most of the variants of uncertain significance which have been functionally characterised utilising heterologous systems are shown in black or by patterned fill. These domains are also identified by a solid bar above the diagram. Most BRCA1 and BRCA2 VUS lie outside these better conserved domains.

the gene, which are not thought to result in nonsense-mediated decay, such as BRCA2 K3326X, and which are associated with only modest increases in cancer risk. ${ }^{24}$

There are currently $\sim 5200$ and $\sim 6800$ distinct germline variants of $B R C A 1$ and $B R C A 2$, respectively, listed in ClinVar. Of these, there are $\sim 1450$ BRCA1 missense mutations, of which 1300 are VUS and an additional 175 have conflicting interpretations. BRCA2, due in part to its larger size at 3418 amino acids, has $\sim 2400$ unique missense variants, of which $\sim 2300$ are VUS and $\sim 320$ have conflicting interpretations listed. Notably, for BRCA2, missense variants ( 2400) are identified most frequently among alterations that affect the coding sequence. Frameshifts are observed with the next highest frequency $(\sim 1800)$, with nonsense $(\sim 550)$ and spice site $(\sim 140)$ variants being observed much less frequently. The list of VUS in BRCA1 and BRCA2 is likely an underestimate, as not all clinical testing laboratories, particularly those from outside of the USA, contribute data to ClinVar. Importantly, greater than $88 \%$ of BRCA1 missense variants and $95 \%$ of BRCA2 missense variants currently listed in ClinVar are unclassified, underscoring the abundant demand for approaches to classify them. Given how frequently they occur and the number that are currently uncharacterised, this review is largely focused on missense variants. It should also be noted that many of the missense variants of $B R C A 1$ and BRCA2 that have been identified are not confined to recognised domains of either of the corresponding proteins (figures 3 and 4). Thus, strategies for classifying variants present anywhere within these proteins are greatly needed.

\section{THERE IS A DEMAND FOR FUNCTIONAL ASSAYS TO CLASSIFY BRCA1/2 VARIANTS}

Since the inability to classify BRCA1 and BRCA2 variants limits the potential utility of screens of cancer genes to inform decisions concerning risk management, and given the prevalence of VUS of these genes, a means for better classification is greatly needed. The classification of missense variants in these genes is particularly difficult, as the genes are large and in silico approaches to classifying variants are not highly sensitive or specific. ${ }^{2125} 26$ Traditionally, VUS in genes conferring Mendelian risk of disease have been classified as disease-associated (ie, pathogenic) using segregation analyses in families. This is a particularly powerful approach when a disease phenotype is relatively rare and multiple multigeneration families with several affected individuals carrying the same rare variant are available for study. Although some BRCA1/2 missense variants have been classified using this approach, it is not feasible for the vast majority of rare variants because:

1. many variants have only been reported in one or two families, thus there is not sufficient power to perform segregation analyses

2. known affected individuals in families are often deceased due to their cancer history

3. breast and ovarian cancer are relatively common in the general population, leading to phenocopies (individuals with the phenotype not due to the family mutation)

4. not all affected individuals in a family are interested in having genetic testing

5. not every individual with pathogenic variants gets cancer

6. some families have diagnoses of cancer on both maternal and paternal sides, making segregation difficult.

Another means that has been used successfully to classify hundreds of missense variants in BRCA1/2 as benign/neutral is allele frequency in large populations. The rationale for this strategy is that because unique pathogenic BRCA1 and BRCA2 missense changes are unlikely to be present at a frequency of greater than $0.1 \%$ or $1 \%$ in the population without phenotypic impacts, any variant in these genes that occurs in an unselected population at a high frequency is likely to be benign.

In silico prediction tools that incorporate features such as evolutionary conservation across species, how dramatic the predicted effect of amino acid substitution is on protein structure and whether the amino acid is positioned in a known functional domain have been used for characterisation of BRCA1/2 VUS. Many of these algorithms are not highly sensitive in isolation and tend to 'over predict' missense changes as pathogenic. ${ }^{27}$ Thus, there is a need to develop better in silico models that show higher specificity and sensitivity; it may be that models will need to be calibrated on a gene-by-gene basis.

To overcome difficulties in classifying BRCA1/2 VUS, the Evidence-Based Network for the Interpretation of Germline 

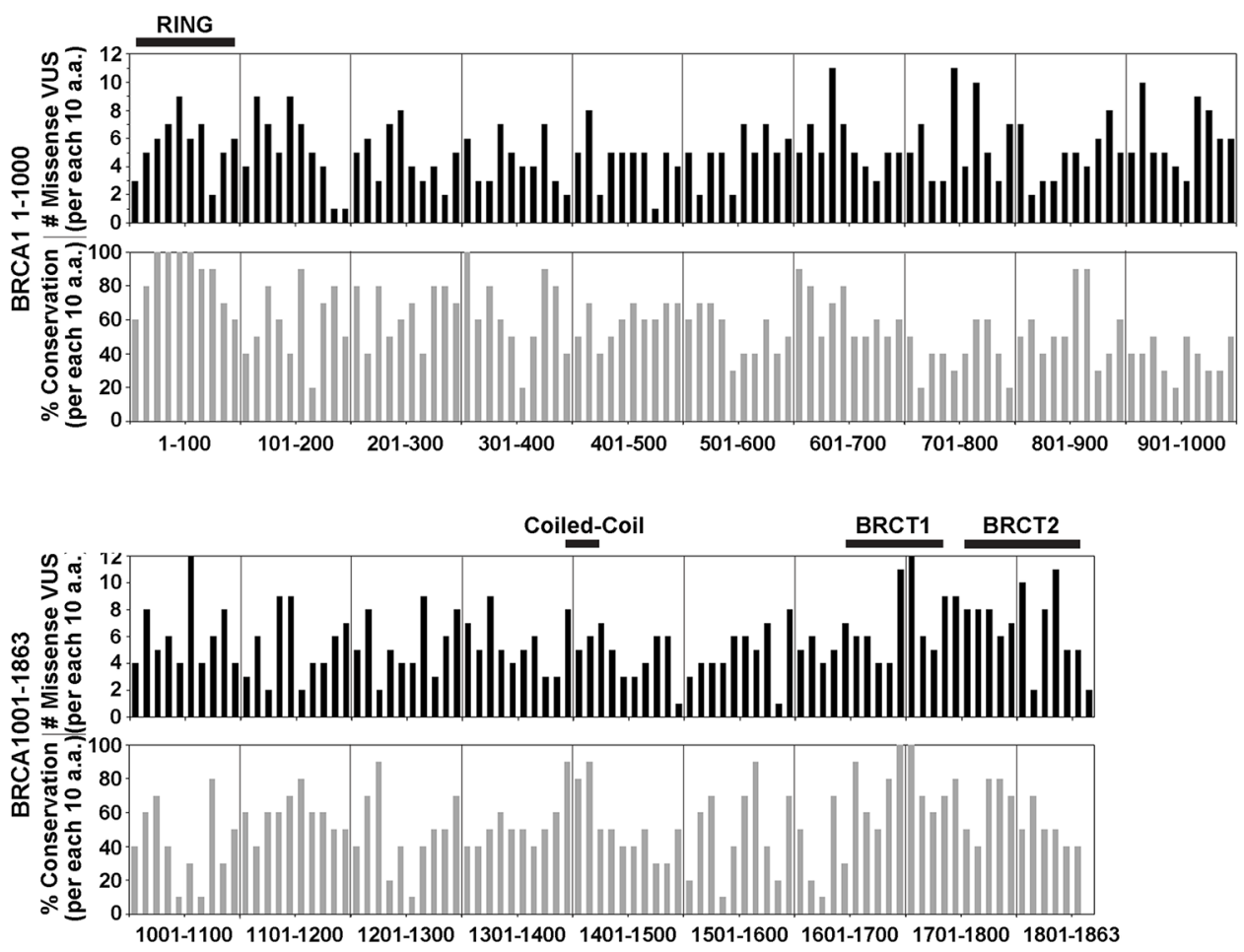

Figure 3 Missense VUS are distributed throughout BRCA1, including to regions of lower conservation. The number of distinct missense BRCA1 VUS listed in ClinVar is shown for groups of 10 amino acids (a.a.) (black bars, above) along with the \% conservation between human and mouse BRCA1 for each group of 10 a.a. (grey bars, below). Vertical dividing lines indicate sets of 100 a.a. Key structural domains are shown by a horizontal black bar above plots of the frequency of missense VUS. Missense BRCA1 VUS that have been reported occur throughout the protein, regardless of the degree of conservation. The graph of percentage conservation demonstrates that there are areas of inexact conservation throughout the protein, including in the BRCT (BRCA1 C terminus) repeats, which have been tested more than most other domains using functional assays. Since inexact conservation could affect the reliability of assays that are based on heterologous expression of BRCA1 in rodent cells, this demonstrates potential advantages of expressing human BRCA1 in human cells. VUS, variants of uncertain significance.

Mutant Alleles (ENIGMA) consortium was formed in 2009. ${ }^{26}$ This is an international collaborative group recognised as an expert panel by ClinVar for interpretation of BRCA1/2 variants. The strength of ENIGMA is that variants that may be seen only once or twice by a single group may be classified by pooling clinical and family segregation data across the entire consortium. Even within this large group, many variants are still too rare to classify based on family and clinical data. ENIGMA and others have developed multifactorial models that incorporate various data elements such as family history, cosegregation of disease in families, co-occurrence of a variant in trans with a previously classified pathogenic variant and histological features (figure 5). ${ }^{28-30}$ Over 100 BRCA1 and 100 BRCA2 variants have been classified using this approach. ${ }^{2630}$

The International Agency for Research on Cancer Working Group (IARC), in collaboration with ENIGMA, developed a multifactorial five-tier classification scheme to classify BRCA1/2 VUS based on cosegregation with cancer in families, co-occurrence with previously identified pathogenic mutations and tumour histopathology, combined with an analysis of sequence conservation across species and the properties of mutated residues. ${ }^{31}$ IARC class 1 and class 2 designate non-pathogenic and likely non-pathogenic variants (probability $\leq 0.01$ and $>0.01$ but $\leq 0.05$ ), respectively. In contrast, classes 5 and 4 represent pathogenic and likely pathogenic variants (probability $\geq 0.99$ and $<0.99$ but $\geq 0.95$ ), respectively. Variants with intermediate probabilities $(>0.05$ but $<0.95)$ remain unclassified and are designated as class 3, largely due to insufficient availability of family or other information (figure 5).
Despite the progress that has been made to develop systematic approaches to classifying missense variants, the vast majority of BRCA1/2 variants are VUS. The critical need for alternative approaches to classify VUS has led several research groups to develop in vitro assays that can be used to screen a variety of $B R C A 1$ and $B R C A 2$ mutations, including missense and in-frame deletions, for effects on BRCA1 and BRCA2 function. ${ }^{2132-38}$ The beauty of functional assays is that they are not dependent on the existence of clinical or family data. Splice anomalies should be identified first and such variants excluded from subsequent DNA repair-related functional tests.

\section{DOMAINS AND ROLES OF BRCA1 AND BRCA2 THAT CAN SERVE AS THE BASIS FOR FUNCTIONAL ASSAYS}

BRCA1 and BRCA2 are large proteins with functional domains distributed both $\mathrm{N}$-terminally and $\mathrm{C}$-terminally, as well as more centrally (figure 2). BRCA1 has a Really Interesting New Gene (RING) domain at its $\mathrm{N}$-terminus (amino acids (a.a.) 8-98) that binds BARD $1,{ }^{1}$ the product of another breast cancer susceptibility gene ${ }^{39}$ which is required for the $\mathrm{E} 3$ ubiquitin ligase activity of the BRCA1-BARD1 heterodimer. ${ }^{40}$ More centrally, there is a coiled-coil motif from a.a. 1367-1437 that binds PALB2. ${ }^{41}$ PALB2 is also the product of a breast cancer susceptibility gene and is a key partner of BRCA2. ${ }^{43} 44$ Finally, there are two BRCT (BRCA1 C terminus) repeats, which mediate binding to Abraxas, BRIP1 and CtIP, from a.a. 1646-1859, very near the C-terminus of BRCA1. ${ }^{45}$ Interestingly, both BRIP1 and Abraxas are also breast cancer susceptibility proteins. ${ }^{39} 4647$ 

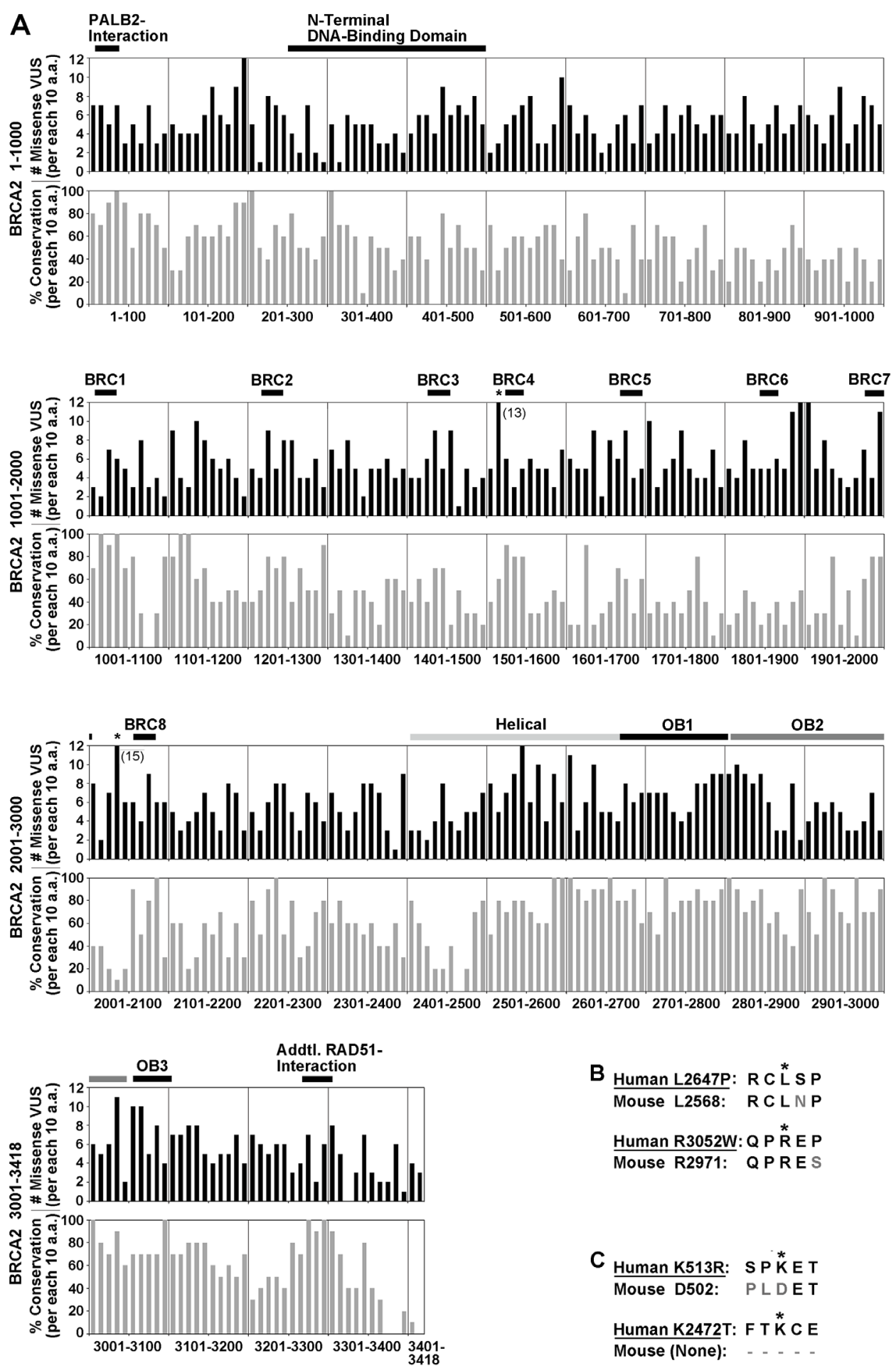

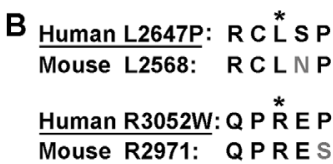

C Human K513R: S P K KET Mouse D502: PLDET Human K2472T: F T K K E

Figure 4 Missense BRCA2 VUS are distributed throughout the protein, including to regions of lower conservation. (A) The number of distinct missense BRCA2 VUS listed in ClinVar is shown for groups of 10 amino acids (a.a.) (black bars, above) along with the \% conservation between human and mouse BRCA2 for each group of 10 a.a. (grey bars, below). Vertical dividing lines indicate sets of 100 a.a. Key structural domains are shown by a horizontal bar above plots of the frequency of missense VUS. The BRC repeats are 25 a.a. motifs dispersed from a.a. 1008-2082 which bind RAD51. The C-terminal DNAbinding domain (DBD) is comprised of a helical domain and three OB (oligonucleotide/oligosaccharide) folds. Reported missense BRCA2 VUS are found throughout the protein regardless of the degree of conservation. The graph of percentage conservation demonstrates that there are areas of relatively low conservation throughout BRCA2, including part of the helical domain, which is in the C-terminal DBD that contains known pathogenic variants. Additionally, the BRC3, BRC5 and BRC6 motifs also have relatively low conservation. In contrast, there are other areas of high conservation that are not contained within known domains. Since inexact conservation could affect the reliability of assays based on heterologous expression of BRCA2 in rodent cells, this demonstrates a potential advantage of expressing human BRCA2 in human cells for assays. (B) Examples of pathogenic (R3052W) and likely pathogenic (L2647P) variants that do not display exact conservation in adjacent residues between human and mouse BRCA2. (C) Examples of benign variants lacking alignment or conservation with mouse BRCA2. Variant residues are indicated by asterisks, non-conserved residues in mouse are shown in grey, and residues without alignment in mouse BRCA2 are indicated by (-) in (B-C). VUS, variants of uncertain significance. 


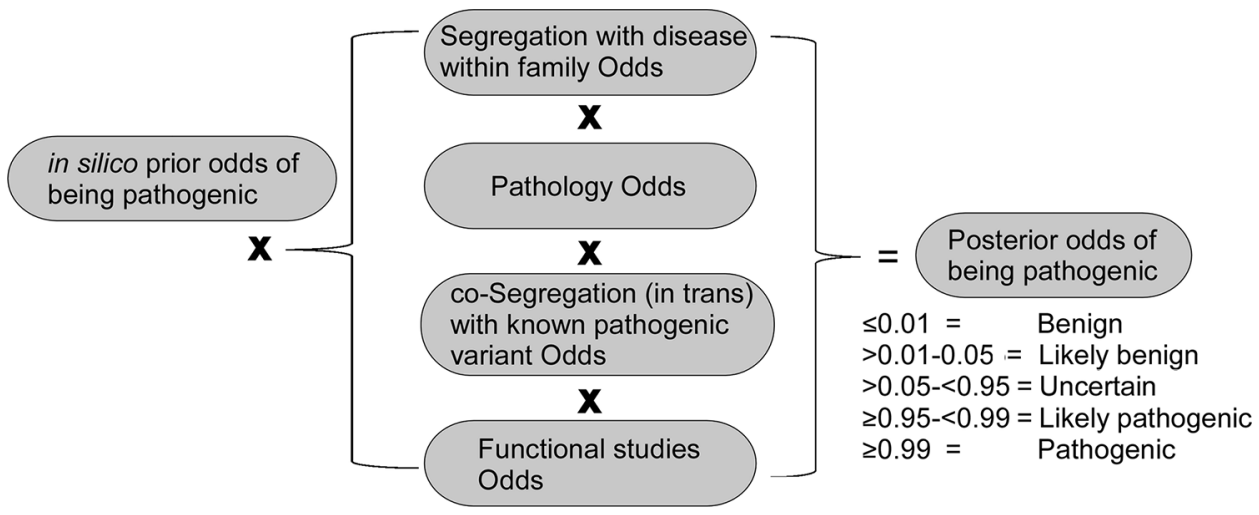

Figure 5 Overview of multifactorial model-based classification of missense VUS. Examples of types of input data used for multifactorial classification of BRCA1/2 missense VUS are described. The posterior probabilities recommended by IARC for the five classes of variant interpretations are noted. IARC, International Agency for Research on Cancer; VUS, variants of uncertain significance.

BRCA2 has an N-terminal domain (a.a. 10-40) that binds to PALB2. ${ }^{44}$ More centrally, there are eight interspersed BRC motifs (a.a. 1008-2082) that bind the RAD51 recombinase. ${ }^{48} 49$ At the C-terminus, there is an additional RAD51 binding region (a.a. 3270-3305), and a helical domain (a.a. 2402-2668) and three OB folds that bind to single-strand DNA (a.a. 2670-3102), which are important for BRCA2 function. ${ }^{50-52}$ Recently, an additional DNA-binding domain (DBD) in BRCA2 has been identified between a.a. 250 and $500 .^{53}$

As a basis for understanding functional assays for BRCA1 and BRCA2 variants, we will begin with a brief overview of the biological roles of these tumour suppressors in cells. BRCA1 has been reported to function in such diverse processes as transcriptional regulation and the control of centrosome number. ${ }^{425455}$ It also has multiple roles in the cellular response to DNA damage, including regulation of the G2 DNA damage checkpoint, ${ }^{55}$ protection of stalled replication forks against nucleolytic degradation, ${ }^{56}$ mediating resistance to ionising radiation (IR) and chemotherapeutic agents, ${ }^{57} 58$ and mediating DNA repair by $\mathrm{HR}^{59}$

Most of the properties of BRCA1 described above have been the basis for functional assays for BRCA1 variants at some point in time. ${ }^{22}$ These studies are catalogued on the BRCA1 Circos Web tool. ${ }^{60}$ Assays based on HR or cellular resistance to DNA damage have been used most recently and may be the most promising. ${ }^{34} 353861$ One reason for this is that these assays have the potential to assess variants located throughout different regions of BRCA1, and therefore have greater general utility. In contrast, while transactivation by BRCA1 may also be used for functional assays, ${ }^{22}$ this is only relevant for VUS located in the extreme C-terminus of BRCA1 where this activity is located. ${ }^{5462}$

Specifically, the function of BRCA1 in HR and cellular resistance to DNA damage requires the RING domain that has a role in the recruitment of BRCA1, ${ }^{34} 3661$ a region from a.a. to 1-324 that interacts with the MRE11-RAD50-NBS1 complex to promote end resection, ${ }^{63}$ and the coiled-coil for recruitment of PALB2-BRCA2-RAD51 to initiate strand invasion. ${ }^{41} 4564$ Additionally, the BRCT repeats are necessary for recruitment of BRCA1 and for binding to the CtIP nuclease as part of end resection. ${ }^{3665}$ Thus, nearly any truncation or variant affecting BRCA1 protein stability inhibits HR. It should also be noted that HR assays and DNA damage sensitivity assays are readily quantifiable, which is highly desirable in functional assays.

BRCA2 also has a role in transcriptional activation, and functions in cytokinesis, the maintenance of G2 checkpoint arrest, the protection of stalled replication forks against degradation, and as a mediator of HR. ${ }^{45} 56$ 66-68 Specifically, BRCA2 regulates the recruitment of RAD51 to sites of DNA damage and the oligomerisation of RAD51 with single-strand DNA that is necessary to form recombination intermediates. ${ }^{45} 6970$ Functional assays based on direct measures of HR or on BRCA2-dependent assembly of RAD51 foci are particularly well suited to assessing BRCA2 VUS. BRCA2 also has a clear role in mediating cellular resistance to DNA damage. ${ }^{49} 52$ Correspondingly, BRCA2 functional assays have focused on HR using reporters and measurements of resistance to DNA damage. ${ }^{3371-73}$ Consistent with this, the function of BRCA2 as a tumour suppressor is attributed to its central role in the DNA damage response. ${ }^{45}$

The use of HR or DNA damage sensitivity assays to assess BRCA2 VUS is also supported by the fact that pathogenic HBOC-associated missense variants of $B R C A 2$ in the N-terminal PALB2-binding domain or the C-terminal DBD disrupt these processes. In comparison to transactivation by BRCA2, which involves only a small domain from a.a. $18-105,{ }^{66} \mathrm{HR}$ and resistance to DNA damage require domains throughout BRCA2. Thus, assays related to these functions of BRCA2 may hold particular promise as a means to assess variants distributed throughout the protein. ${ }^{33} 4570-73$ It does not appear, however, that assays based on replication fork stability, which is related to DNA repair, accurately predict the cancer risk associated with $B R C A 2$ VUS; the pathogenic Y3308X mutant promotes fork stability. ${ }^{72} 74$

\section{REVIEW OF FUNCTIONAL ASSAYS FOR BRCA1 VUS THAT USE THE FULL-LENGTH PROTEIN}

As discussed in the previous section, assays based on HR and/or resistance to DNA damaging agents have emerged as the standard for the functional characterisation of BRCA1 VUS. Since multiple domains of BRCA1 are required for HR and resistance to DNA damage, assays with fragments of BRCA1, such as a recent assay based on the ubiquitin-ligase activity of the RING domain, ${ }^{37}$ may not be as accurate as assays that use the fulllength protein. Thus, we will focus here on cell-based functional studies that have examined BRCA1 variants in the context of the full-length protein. Overall, the four studies of BRCA1 VUS discussed here have been validated as reliable for the RING and BRCT domains. ${ }^{3453861}$

Validation of functional assays utilising neutral and deleterious standards is necessary to establish the particular system 
that is employed. ${ }^{22}$ The studies we consider here have all been validated with such standards. The first such assay system established for BRCA1 was based on rescue of proliferative defects resulting from deficiency of mouse embryonic stem cells (ESCs) for endogenous Brca1 and employed heterologous expression of human BRCA1 in ESCs. ${ }^{35}$ Two missense variants of the BRCT repeats were examined, along with one neutral missense variant and three deleterious variants (two frameshift/one missense). Whether rescue of a proliferative defect, in the absence of exogenous DNA damage, is highly relevant to cancer susceptibility is uncertain.

Subsequently, another study in mouse ESCs characterised 74 missense BRCA1 VUS. ${ }^{61}$ To date, this is the largest individual functional study of BRCA1 VUS performed using the full-length protein. One reason for the relatively greater capacity of this assay was the use of a BRCA1 cDNA, encoding wild-type BRCA1 and variants, rather than a BAC to carry BRCA1. Still, this approach may not be rapid enough for a higher throughput analysis. Three neutral missense variants and five deleterious variants (two missense/three frameshift) were used as controls. All VUS found to be deleterious failed to confer resistance to cisplatin, and were restricted to the RING domain and the BRCT repeats. A subset of these missense VUS was also examined by measurements of HR using a reporter assay. Predictions based on HR and resistance to cisplatin agreed for all variants except R1699Q. R1699Q was defective for resistance to cisplatin but showed differences in HR that were not significantly different from the activity of wild-type BRCA1. Family-based studies have characterised R1699Q as an intermediate breast and ovarian cancer risk, which may explain the discordant functional results and underscores the need to include segregation analyses whenever possible. ${ }^{75}$

Systems to test BRCA1 and BRCA2 VUS in ESCs, including those described above, typically have constitutive knockout of one allele and conditional deletion of the other following introduction of human BRCA1 or BRCA2. Notably, due to multiple genetic manipulations and selection steps, these systems are labour-intensive and relatively slow, and therefore likely may not have the capacity to analyse the number of variants necessary to have an important impact.

BRCA1 has $58 \%$ conservation between humans and mice. ${ }^{76}$ As shown in figure 3 , conservation is often high at the $\mathrm{N}$-termini and C-termini of BRCA1, which contain the RING domain and BRCT repeats, respectively. It should be noted that pathogenic missense variants of BRCA1 in ClinVar reside predominantly in these RING and BRCT repeats. Importantly, systems based on heterologous expression of human BRCA1 in mice may not accurately assess variants located in domains with lower levels of conservation. It is also unclear whether mouse ESCs are a reliable model for preneoplastic events that increase the risk of developing cancer in human epithelial cells of the breast and ovaries.

Two additional studies characterising BRCA1 variants in HeLa cells, depleted of endogenous BRCA1 utilising an RNAi, have been conducted by the laboratory of Jeffery Parvin. ${ }^{34} 38$ In the first of these studies, ${ }^{34}$ five deleterious and one neutral variant, all missense, along with nine N-terminal VUS, all present in the first 71 amino acids of BRCA1, were examined based on measurements of HR. Interestingly, deletions of a.a. 1-302, $305-770,775-1292$ and $1527-1863$ all compromised HR to some degree, further suggesting that different regions of BRCA1 are all required for HR or protein stability. The second study examined seven pathogenic and one non-pathogenic missense variants, and four missense VUS present from a.a. 90-170. ${ }^{38}$
Notably, a comparison of HR and another DNA repair process, single-strand annealing (SSA), showed that HR may more accurately distinguish previously classified benign and pathogenic variants. Thus, HR is a more reliable assay for the classification of BRCA1 VUS than SSA. While these assays were conducted in human cells, there are, nevertheless, certain concerns about them. Since HeLa cells are already transformed, they may not accurately model the role of compromised HR activity of BRCA1 in tumour initiation. Further, variable depletion of BRCA1 using RNAi could potentially make it difficult to compare the results of functional assays conducted in different laboratories. Certain VUS overlapped in the four studies described above, resulting in collective characterisation of 86 distinct missense variants.

\section{REVIEW OF FUNCTIONAL ASSAYS FOR BRCA2 VUS THAT USE THE FULL-LENGTH PROTEIN}

Given how BRCA2 is believed to function as a tumour suppressor, assays related to DNA repair are directly relevant to predicting the impact of BRCA2 variants on cancer risk and therapeutic response. Additionally, such assays have demonstrated high sensitivity and specificity for predicting known benign and pathogenic variants. For these reasons, DNA repair-related assays are considered here. ${ }^{21}$

Since DNA repair-related domains are distributed throughout BRCA2, as discussed earlier, such assays should be based on expression of full-length BRCA2. BRCA2 is even larger than BRCA1 (the protein is $\sim 390 \mathrm{kDa}$ and the cDNA is $10254 \mathrm{bp}$ ). Thus, it has been difficult to express full-length BRCA2 in human cells using a cDNA. ${ }^{6973}$ As such, some functional studies of BRCA2 VUS have been based on heterologous expression of full-length BRCA2 variants in mouse ESCs using BACs. ${ }^{7172}$ These studies, in the laboratory of Shyam Sharan, focused on VUS in the N-terminal PALB2-binding domain and the C-terminal DBD, where conservation between mouse and human BRCA2 is generally high (figure 4). Less than 10 distinct missense BRCA2 VUS were examined in each of these studies for the capacity to rescue proliferative defects resulting from conditional deletion of Brca2. ${ }^{7172}$ These studies employed one neutral missense and three deleterious variants (one missense/two frameshift), ${ }^{72}$ and two benign and one neutral missense variants, respectively. ${ }^{71}$ Importantly, results with benign and pathogenic standards corresponded precisely in the ability to rescue proliferative defects, to promote HR, measured utilising a reporter assay or based on the assembly of RAD51 foci, and to promote resistance/sensitivity to DNA damage. Although studies with larger numbers of variants are needed as a basis for more definitive conclusions, this suggests the possibility that these assays may be used interchangeably to classify BRCA2 VUS.

Two studies led by the laboratory of Fergus Couch heterologously expressed full-length human BRCA2 in BRCA2-deficient VC-8 hamster lung fibroblast cells. ${ }^{33} 73$ They began their studies by transiently expressing BRCA2 in human cells, but had difficulty achieving efficient expression. ${ }^{73}$ Since the reliability of assays and the ability to compare results from independent experiments are greatly facilitated by efficient and stable expression, the investigators ultimately turned to cDNA-based expression in VC-8 hamster cells. In one of these studies, they tested one nonsense variant which they defined as neutral and one frameshift mutation they defined as deleterious for resistance to mitomycin C (MMC) or IR. ${ }^{73}$ They also tested seven BRCA2 VUS for resistance to DNA damage, most of which were additionally assayed for activities in HR and suppression of centrosome amplification. All but one variant, T2515I, gave 
concordant results between these different assays. T2515I was deficient for resistance to DNA damage but was intermediate for HR and centrosome amplification. This again emphasises the importance of assay selection and underscores the need for setting cut-offs to distinguish variants associated with no, partial or full loss of function. In a subsequent study by this same group, ${ }^{33} 13$ pathogenic/likely pathogenic and 17 non-pathogenic/likely non-pathogenic missense standards were used to set cut-offs for interpreting the results for 33 missense VUS of the C-terminal DBD of BRCA2.

When overlap is accounted for, the above studies conducted using full-length BRCA2 together considered 54 missense VUS. Therefore, only 86 and 54 missense VUS of BRCA1 and BRCA2, respectively, have been functionally characterised. Assays with a greater capacity must therefore be developed to keep pace with demand, since $\sim 1300$ and $\sim 2300$ distinct missense VUS of $B R C A 1$ and $B R C A 2$, respectively, are currently listed in ClinVar.

Another issue with the studies of BRCA2 VUS described above is that they were all based on heterologous expression in rodent cells. Mouse and human BRCA2 have 59\% conservation. ${ }^{77}$ As examples of issues raised by inexact conservation, non-conservative changes two and one a.a., respectively, C-terminal to the IARC class 5 (pathogenic) R3052W variant and the class 4 (likely pathogenic) L2647P variant, both of which are present in the relatively highly conserved C-terminal DBD of BRCA2, are shown in figure 4B. Two other class 5 pathogenic variants present in this domain, W2626C and I2627P, of eight proposed as part of a validation panel for functional studies of BRCA2 VUS, ${ }^{21}$ have non-identical amino acid residues within two positions of the variant residue (not shown). The fact that inexact conservation can potentially affect pathogenic variants is important because this could lead to inappropriate classification.

Heterologous assays of BRCA2, as well as BRCA1, may have particular difficulty accurately assessing variants in areas of lower level conservation. As an example, here we consider the case of BRCA2. Of the 72 IACR class 1 neutral variants proposed for the validation of functional studies, ${ }^{21} 60$ are outside the highly conserved PALB2-binding and DBD domains. For 34 of these 60 neutral variants (57\%), the variant residue does not align with the mouse sequence (including H1918Y, L2396F, N2436I, K2472T) or the corresponding residue is not conserved in mice (including N56T, K513R, R1190W, C1265S and G1771D). An example is shown for K2472T (figure 4C), which lacks alignment with corresponding residues in mouse BRCA2 for a.a. 2460-2478, suggesting the possibility that a subdomain in which this variant resides may not be present in mouse BRCA2. Additionally, $\mathrm{K} 513 \mathrm{R}$ provides an example where there is a non-conservative change in the mouse sequence corresponding to the position of the variant, flanked by non-conserved residues. Such lack of conservation is a potential issue since many of the functions of BRCA2, as well as BRCA1, are mediated by protein interactions. Interacting proteins in rodent cells may not interact as efficiently with human BRCA1 or BRCA2 in domains with low conservation. The consequence of this is that certain domains of human BRCA1 or BRCA2 may not have their normal activities in rodent cells due to low conservation. Thus, the effect of variants in these domains may be underestimated or not measured at all. Therefore, assays in human cells are instead necessary to assess cancer risk, as well as increased sensitivity to chemotherapy for the many BRCA1 or BRCA2 variants (shown in figure 3,4 ) that are present outside of highly conserved regions. Again, while most pathogenic variants identified so far reside in highly conserved domains, the ability to functionally characterise variants in other areas is necessary to fully empower genetic screens of BRCA1/2.
ASSESSMENT OF WHAT IS NEEDED TO DRIVE MORE EFFICIENT AND RELIABLE CLASSIFICATION OF BRCA1/2 VUS Essential controls for functional assays

Functional assays to characterise BRCA1 and BRCA2 missense VUS need positive and negative controls to validate the sensitivity and specificity of the assay. Missense variants that have been clinically classified as benign should behave as wild-type and those classified as pathogenic should behave similar to knockout cells or truncating variants. Controls should include those that have been classified using robust multifactorial models and/or for which the significance has been evaluated with genetic evidence such as segregation.

\section{What functional assays are most relevant for predicting pathogenicity?}

Among the many functions of BRCA1 and BRCA2, HR may be especially important for preventing cancer susceptibility. In most studies of both BRCA1 and BRCA2 VUS, HR is a highly sensitive and specific assay for missense variants, as discussed in the two previous sections. In comparison, while sensitivity to PARP inhibitors may have a reasonably high-throughput capacity and is highly relevant for guiding treatment, it may not be as relevant or accurate as HR for predicting cancer risk. For example, in a mouse model, the pathogenic BRCA1 C61G variant, which is well-associated with HBOC and causes tumours in mice, does not appear to render the tumours sensitive to platinum drugs or PARP inhibition. ${ }^{78}$

\section{Tissue and model specificity}

A relatively unaddressed issue in the development of optimal functional assays for BRCA1/2 is whether tissue specificity matters. BRCA1 and BRCA2 are important for DNA repair across tissue types. However, there is tissue specificity for which organs and cells of origin are at highest risk for developing tumours in carriers of these mutations. Thus, there are likely tissue-specific factors that may modulate the context in which these mutations influence cancer development. There has been no direct sideby-side comparison of variant assays from breast/ovarian cells to cell lines derived from other tissues. Similarly, functional assays for BRCA1/2 have been done in cells from organisms such as mouse ESCs, yeast and hamster. ${ }^{33} 356171-7379$ Aside from issues of inexact conservation, there may be subtle differences between human and other organisms that could impact results.

\section{Improved systems for CDNA-based expression of BRCA1 or BRCA2 in human cells with a corresponding deficiency} Expression of full-length BRCA1 or BRCA2 is difficult, especially for BRCA2, and this has led to the use of heterologous expression systems. Additionally, there are few BRCA1-deficient and BRCA2-deficient human cell lines available for assays, ${ }^{80-83}$ and not necessarily in the most relevant tissue type or with the appropriate transformation/immortalisation status. Overcoming these challenges may require innovative approaches to gene editing and gene expression. Such innovation, however, should lead to the capacity to conduct higher throughput assays using cDNA-based approaches in human tissue-specific models that better predict cancer risk or, separately, therapeutic response.

\section{Incorporation of data from functional assays into multifactorial analyses}

A final important consideration is how best to incorporate data from functional assays for BRCA1 and BRCA2 into multifactorial predictive models. Statistical algorithms calculating 
the probability of pathogenicity can be developed using the variances of distribution of a quantitative functional assay along with the means and confidence intervals (CIs) of each variant being studied, including variants of known classification. A pathogenicity probability based on these can be used to calculate likelihood ratios. Likelihood ratios can be integrated with other available factors in the model to provide an overall likelihood probability of pathogenicity for a variant (figure 5). One example of this is VarCall, a computational tool that incorporated functional data from the C-terminal domain of BRCA1 to determine the likelihood of pathogenicity for over 200 missense variants. ${ }^{84}$ The power of predicting pathogenicity of missense variants in this domain increased dramatically, suggesting that this type of computational algorithm may be quite useful once large amounts of robust functional data are available.

\section{CONCLUSION}

Collectively, these studies show the power of functional assays for predicting pathogenicity of BRCA1/2 VUS. Moving forward, it will be important to define the optimal assays to use for BRCA1/2 VUS classification, which can be incorporated into multifactorial statistical analysis models that also include any available data on cosegregation and tumour pathology.

Contributors AET and PRA both contributed to conceptualisation and writing of the manuscript.

\section{Competing interests None declared.}

Provenance and peer review Not commissioned; externally peer reviewed.

(c) Article author(s) (or their employer(s) unless otherwise stated in the text of the article) 2017. All rights reserved. No commercial use is permitted unless otherwise expressly granted.

\section{REFERENCES}

1 Miki Y, Swensen J, Shattuck-Eidens D, Futreal PA, Harshman K, Tavtigian S, Liu Q, Cochran C, Bennett LM, Ding W, Bell R, Rosenthal J, Hussey C, Tran T, McClure M, Frye C, Hattier T, Phelps R, Haugen-Strano A, Katcher H, Yakumo K, Gholami Z, Shaffer D, Stone S, Bayer S, Wray C, Bogden R, Dayananth P, Ward J, Tonin P, Narod S, Bristow PK, Norris FH, Helvering L, Morrison P, Rosteck P, Lai M, Barrett JC, Lewis C, Neuhausen S, Cannon-Albright L, Goldgar D, Wiseman R, Kamb A, Skolnick MH. A strong candidate for the breast and ovarian cancer susceptibility gene BRCA1. Science 1994;266:66-71.

2 Tavtigian SV, Simard J, Rommens J, Couch F, Shattuck-Eidens D, Neuhausen S, Merajver S, Thorlacius S, Offit K, Stoppa-Lyonnet D, Belanger C, Bell R, Berry S, Bogden R, Chen Q, Davis T, Dumont M, Frye C, Hattier T, Jammulapati S, Janecki T, Jiang P, Kehrer R, Leblanc JF, Mitchell JT, McArthur-Morrison J, Nguyen K, Peng Y, Samson C, Schroeder M, Snyder SC, Steele L, Stringfellow M, Stroup C, Swedlund B, Swense J, Teng D, Thomas A, Tran T, Tranchant M, Weaver-Feldhaus J, Wong AK, Shizuya H, Eyfjord JE, Cannon-Albright L, Tranchant M, Labrie F, Skolnick MH, Weber B, Kamb A, Goldgar DE. The complete BRCA2 gene and mutations in chromosome 13q-linked kindreds. Nat Genet 1996;12:333-7.

3 Kapoor NS, Curcio LD, Blakemore CA, Bremner AK, McFarland RE, West JG, Banks KC Multigene panel testing detects equal rates of pathogenic BRCA1/2 mutations and has a higher diagnostic yield compared to limited BRCA1/2 analysis alone in patients at risk for hereditary breast cancer. Ann Surg Oncol 2015;22:3282-8.

4 Kast K, Rhiem K, Wappenschmidt B, Hahnen E, Hauke J, Bluemcke B, Zarghooni V, Herold N, Ditsch N, Kiechle M, Braun M, Fischer C, Dikow N, Schott S, Rahner N, Niederacher D, Fehm T, Gehrig A, Mueller-Reible C, Arnold N, Maass N, Borck G, de Gregorio N, Scholz C, Auber B, Varon-Manteeva R, Speiser D, Horvath J, Lichey N, Wimberger P, Stark S, Faust U, Weber BH, Emons G, Zachariae S, Meindl A, Schmutzler RK, Engel C. German Consortium for Hereditary Breast and Ovarian Cancer. Revalence of BRCA1/2 germline mutations in 21401 families with breast and ovarian Cancer. J Med Genet 2016:53:465-71.

5 Graffeo R, Livraghi L, Pagani O, Goldhirsch A, Partridge AH, Garber JE. Time to incorporate germline multigene panel testing into breast and ovarian cancer patient care. Breast Cancer Res Treat 2016;160:393-410.

6 Rosenthal ET, Evans B, Kidd J, Brown K, Gorringe H, van Orman M, Manley S. Increased identification of candidates for high-risk breast cancer screening through expanded genetic testing. J Am Coll Radiol 2017;14:561-8.

7 Petrucelli N, Daly MB, Pal T. BRCA1- and BRCA2-Associated hereditary breast and ovarian Cancer. GeneReviews(R). University of Washington 2016.
8 Nelson HD, Fu R, Goddard K, Mitchell JP, Okinaka-Hu L, Pappas M, Zakher B. 2013. Risk Assessment, Genetic Counseling, and Genetic Testing for BRCA-Related Cancer: Systematic Review to Update the U.S. Preventive Services Task Force Recommendation: U.S. Preventative Services Task Force Evidence Syntheses, Agency for Healthcare Research and Quality. Rep. \# 12-05164-EF-1.

9 Rebbeck TR, Kauff ND, Domchek SM. Meta-analysis of risk reduction estimates associated with risk-reducing salpingo-oophorectomy in BRCA1 or BRCA2 mutation carriers. J Nat/ Cancer Inst 2009;101:80-7.

10 Daly MB, Pilarski R, Berry M, Buys SS, Farmer M, Friedman S, Garber JE, Kauff ND, Khan S, Klein C, Kohlmann W, Kurian A, Litton JK, Madlensky L, Merajver SD, Offit K, Pal T, Reiser G, Shannon KM, Swisher E, Vinayak S, Voian NC, Weitzel JN, Wick MJ, Wiesner GL, Dwyer M, Darlow S. NCCN guidelines Insights: genetic/familial high-risk assessment: breast and ovarian, version 2.2017. J Natl Compr Canc Netw 2017;15:9-20.

11 Alsop K, Fereday S, Meldrum C, deFazio A, Emmanuel C, George J, Dobrovic A, Birrer MJ, Webb PM, Stewart C, Friedlander M, Fox S, Bowtell D, Mitchell G. BRCA mutation frequency and patterns of treatment response in BRCA mutation-positive women with ovarian cancer: a report from the Australian Ovarian Cancer Study Group. J Clin Oncol 2012;30:2654-63.

12 Dann RB, DeLoia JA, Timms KM, Zorn KK, Potter J, Flake DD, Lanchbury JS, Krivak TC. BRCA1/2 mutations and expression: response to platinum chemotherapy in patients with advanced stage epithelial ovarian cancer. Gynecol Oncol 2012;125:677-82.

13 Maxwell KN, Domchek SM. Cancer treatment according to BRCA1 and BRCA2 mutations. Nat Rev Clin Oncol 2012:9:520-8.

14 Pennington KP, Walsh T, Harrell MI, Lee MK, Pennil CC, Rendi MH, Thornton A, Norquist BM, Casadei S, Nord AS, Agnew KJ, Pritchard CC, Scroggins S, Garcia RL, King MC, Swisher EM. Germline and somatic mutations in homologous recombination genes predict platinum response and survival in ovarian, fallopian tube, and peritoneal carcinomas. Clin Cancer Res 2014;20:764-75.

15 Walsh CS. Two decades beyond BRCA1/2: homologous recombination, hereditary cancer risk and a target for ovarian cancer therapy. Gynecol Oncol 2015;137:343-50.

16 Suh DH, Lee KH, Kim K, Kang S, Kim JW. Major clinical research advances in gynecologic cancer in 2014. J Gynecol Oncol 2015;26:156-67.

17 Anon. Rucaparib approved for ovarian cancer. Cancer Discov 2017;7:120-1.

18 Konecny GE, Kristeleit RS. PARP inhibitors for BRCA1/2-mutated and sporadic ovarian cancer: current practice and future directions. Br J Cancer 2016;115:1157-73.

19 King MC, Levy-Lahad E, Lahad A. Population-based screening for BRCA1 and BRCA2: 2014 lasker award. JAMA 2014;312:1091-2.

20 Rosenberg SM, Ruddy KJ, Tamimi RM, Gelber S, Schapira L, Come S, Borges VF, Larsen $\mathrm{B}$, Garber JE, Partridge AH. BRCA1 and BRCA2 mutation testing in young women with breast cancer. JAMA Oncol 2016;2:730-6.

21 Guidugli L, Carreira A, Caputo SM, Ehlen A, Galli A, Monteiro AN, Neuhausen SL, Hansen TV, Couch FJ, Vreeswijk MP; ENIGMA Consortium. Functional assays for analysis of variants of uncertain significance in BRCA2. Hum Mutat 2014;35:151-64.

22 Millot GA, Carvalho MA, Caputo SM, Vreeswijk MP, Brown MA, Webb M, Rouleau E, Neuhausen SL, Hansen T, Galli A, Brandão RD, Blok MJ, Velkova A, Couch FJ, Monteiro AN; ENIGMA Consortium Functional Assay Working Group. A guide for functional analysis of BRCA1 variants of uncertain significance. Hum Mutat 2012;33:1526-37.

23 Landrum MJ, Lee JM, Benson M, Brown G, Chao C, Chitipiralla S, Gu B, Hart J, Hoffman D, Hoover J, Jang W, Katz K, Ovetsky M, Riley G, Sethi A, Tully R, VillamarinSalomon R, Rubinstein W, Maglott DR. ClinVar: public archive of interpretations of clinically relevant variants. Nucleic Acids Res 2016;44:D862-8.

24 Meeks HD, Song H, Michailidou K, Bolla MK, Dennis J, Wang Q, Barrowdale D, Frost D, McGuffog L, Ellis S, Feng B, Buys SS, Hopper JL, Southey MC, Tesoriero A, James PA, Bruinsma F, Campbell IG, Broeks A, Schmidt MK, Hogervorst FB, Beckman MW, Fasching PA, Fletcher O, Johnson N, Sawyer EJ, Riboli E, Banerjee S, Menon U, Tomlinson I, Burwinkel B, Hamann U, Marme F, Rudolph A, Janavicius R, Tihomirova L, Tung N, Garber J, Cramer D, Terry KL, Poole EM, Tworoger SS, Dorfling CM, van Rensburg EJ, Godwin AK, Guénel P, Truong T, Stoppa-Lyonnet D, Damiola F, Mazoyer S, Sinilnikova OM, Isaacs C, Maugard C, Bojesen SE, Flyger H, Gerdes AM, Hansen TV, Jensen A, Kjaer SK, Hogdall C, Hogdall E, Pedersen IS, Thomassen M, Benitez J, González-Neira A, Osorio A, Hoya ML, Segura PP, Diez O, Lazaro C, Brunet J, AntonCulver $\mathrm{H}$, Eunjung L, John EM, Neuhausen SL, Ding YC, Castillo D, Weitzel JN, Ganz PA, Nussbaum RL, Chan SB, Karlan BY, Lester J, Wu A, Gayther S, Ramus SJ, Sieh W, Whittermore AS, Monteiro AN, Phelan CM, Terry MB, Piedmonte M, Offit K, Robson M, Levine D, Moysich KB, Cannioto R, Olson SH, Daly MB, Nathanson KL, Domchek SM, Lu KH, Liang D, Hildebrant MA, Ness R, Modugno F, Pearce L, Goodman MT, Thompson PJ, Brenner H, Butterbach K, Meindl A, Hahnen E, Wappenschmidt B, Brauch H, Brüning T, Blomqvist C, Khan S, Nevanlinna H, Pelttari LM, Aittomäki K, Butzow R, Bogdanova NV, Dörk T, Lindblom A, Margolin S, Rantala J, Kosma VM, Mannermaa A, Lambrechts D, Neven P, Claes KB, Maerken TV, Chang-Claude J, FleschJanys D, Heitz F, Varon-Mateeva R, Peterlongo P, Radice P, Viel A, Barile M, Peissel B, Manoukian S, Montagna M, Oliani C, Peixoto A, Teixeira MR, Collavoli A, Hallberg E, Olson JE, Goode EL, Hart SN, Shimelis H, Cunningham JM, Giles GG, Milne RL, Healey S, Tucker K, Haiman CA, Henderson BE, Goldberg MS, Tischkowitz M, Simard J, Soucy P, Eccles DM, Le N, Borresen-Dale AL, Kristensen V, Salvesen HB, Bjorge L, Bandera EV, Risch H, Zheng W, Beeghly-Fadiel A, Cai H, Pylkäs K, Tollenaar RA, Ouweland AM, Andrulis IL, Knight JA, Narod S, Devilee P, Winqvist R, Figueroa J, Greene MH, Mai PL, 
Loud JT, García-Closas M, Schoemaker MJ, Czene K, Darabi H, McNeish I, Siddiquil N, Glasspool R, Kwong A, Park SK, Teo SH, Yoon SY, Matsuo K, Hosono S, Woo YL, Gao YT, Foretova L, Singer CF, Rappaport-Feurhauser C, Friedman E, Laitman Y, Rennert G, Imyanitov EN, Hulick PJ, Olopade OI, Senter L, Olah E, Doherty JA, Schildkraut J, Koppert LB, Kiemeney LA, Massuger LF, Cook LS, Pejovic T, Li J, Borg A, Öfverholm A, Rossing MA, Wentzensen N, Henriksson K, Cox A, Cross SS, Pasini BJ, Shah M, Kabisch M, Torres D, Jakubowska A, Lubinski J, Gronwald J, Agnarsson BA, Kupryjanczyk J, Moes-Sosnowska J, Fostira F, Konstantopoulou I, Slager S, Jones M, Antoniou AC, Berchuck A, Swerdlow A, Chenevix-Trench G, Dunning AM, Pharoah PD, Hall P, Easton DF, Couch FJ, Spurdle AB, Goldgar DE. EMBRACE; kConFab Investigators; Australia Ovarian Cancer Study Group; HEBON; GEMO Study Collaborators; OCGN;PRostate cancer AssoCiation group To Investigate Cancer Associated aLterations in the genome. BRCA2 polymorphic stop codon $\mathrm{K} 3326 \mathrm{X}$ and the risk of breast, prostate, and ovarian cancers. J Natl Cancer Inst 2016;108:djv315.

25 Lindor NM, Guidugli L, Wang X, Vallée MP, Monteiro AN, Tavtigian S, Goldgar DE, Couch FJ. A review of a multifactorial probability-based model for classification of BRCA1 and BRCA2 variants of uncertain significance (VUS). Hum Mutat 2012;33:8-21

26 Spurdle AB, Healey S, Devereau A, Hogervorst FB, Monteiro AN, Nathanson KL, Radice P, Stoppa-Lyonnet D, Tavtigian S, Wappenschmidt B, Couch FJ, Goldgar DE; ENIGMA. ENIGMA--evidence-based network for the interpretation of germline mutant alleles: an international initiative to evaluate risk and clinical significance associated with sequence variation in BRCA1 and BRCA2 genes. Hum Mutat 2012;33:2-7.

27 Kerr ID, Cox HC, Moyes K, Evans B, Burdett BC, van Kan A, McElroy H, Vail PJ, Brown KL, Sumampong DB, Monteferrante NJ, Hardman KL, Theisen A, Mundt E, Wenstrup $\mathrm{RJ}$, Eggington JM. Assessment of in silico protein sequence analysis in the clinical classification of variants in cancer risk genes. J Community Genet 2017;8:87-95.

28 Chenevix-Trench G, Healey S, Lakhani S, Waring P, Cummings M, Brinkworth R, Deffenbaugh AM, Burbidge LA, Pruss D, Judkins T, Scholl T, Bekessy A, Marsh A, Lovelock P, Wong M, Tesoriero A, Renard H, Southey M, Hopper JL, Yannoukakos K, Brown M, Easton D, Tavtigian SV, Goldgar D, Spurdle AB; KConFab Investigators. Genetic and histopathologic evaluation of BRCA1 and BRCA2 DNA sequence variants of unknown clinical significance. Cancer Res 2006;66:2019-27.

29 Easton DF, Deffenbaugh AM, Pruss D, Frye C, Wenstrup RJ, Allen-Brady K, Tavtigian SV Monteiro AN, Iversen ES, Couch FJ, Goldgar DE. A systematic genetic assessment of 1,433 sequence variants of unknown clinical significance in the BRCA1 and BRCA2 breast cancer-predisposition genes. Am J Hum Genet 2007;81:873-83.

30 Spearman AD, Sweet K, Zhou XP, McLennan J, Couch FJ, Toland AE. Clinically applicable models to characterize BRCA1 and BRCA2 variants of uncertain significance. J Clin Oncol 2008;26:5393-400.

31 Plon SE, Eccles DM, Easton D, Foulkes WD, Genuardi M, Greenblatt MS, Hogervorst FB, Hoogerbrugge N, Spurdle AB, Tavtigian SV; IARC Unclassified Genetic Variants Working Group. Sequence variant classification and reporting: recommendations for improving the interpretation of cancer susceptibility genetic test results. Hum Mutat 2008;29:1282-91.

32 Quiles F, Fernández-Rodríguez J, Mosca R, Feliubadaló L, Tornero E, Brunet J, Blanco I, Capellá G, Pujana MÀ, Aloy P, Monteiro A, Lázaro C. Functional and structural analysis of C-terminal BRCA1 missense variants. PLoS One 2013;8:e61302.

33 Guidugli L, Pankratz VS, Singh N, Thompson J, Erding CA, Engel C, Schmutzler R, Domchek S, Nathanson K, Radice P, Singer C, Tonin PN, Lindor NM, Goldgar DE, Couch FJ. A classification model for BRCA2 DNA binding domain missense variants based on homology-directed repair activity. Cancer Res 2013;73:265-75.

34 Ransburgh DJ, Chiba N, Ishioka C, Toland AE, Parvin JD. Identification of breast tumor mutations in BRCA1 that abolish its function in homologous DNA recombination. Cancer Res 2010;70:988-95.

35 Chang S, Biswas K, Martin BK, Stauffer S, Sharan SK. Expression of human BRCA1 variants in mouse ES cells allows functional analysis of BRCA1 mutations. I Clin Invest 2009;119:3160-71.

36 Au WW, Henderson BR. The BRCA1 RING and BRCT domains cooperate in targeting BRCA1 to ionizing radiation-induced nuclear foci. J Biol Chem 2005;280:6993-7001.

37 Starita LM, Young DL, Islam M, Kitzman JO, Gullingsrud J, Hause RJ, Fowler DM, Parvin JD, Shendure J, Fields S. Massively parallel functional analysis of BRCA1 RING domain variants. Genetics 2015;200:413-22.

38 Towler WI, Zhang J, Ransburgh DJ, Toland AE, Ishioka C, Chiba N, Parvin JD. Analysis of BRCA1 variants in double-strand break repair by homologous recombination and single-strand annealing. Hum Mutat 2013:34:439-45.

39 Couch FJ, Hart SN, Sharma P, Toland AE, Wang X, Miron P, Olson JE, Godwin AK, Pankratz VS, Olswold C, Slettedahl S, Hallberg E, Guidugli L, Davila JI, Beckmann MW, Janni W, Rack B, Ekici AB, Slamon DJ, Konstantopoulou I, Fostira F, Vratimos A, Fountzilas G, Pelttari LM, Tapper WJ, Durcan L, Cross SS, Pilarski R, Shapiro CL, Klemp J, Yao S, Garber J, Cox A, Brauch H, Ambrosone C, Nevanlinna H, Yannoukakos D, Slager SL, Vachon CM, Eccles DM, Fasching PA. Inherited mutations in 17 breast cancer susceptibility genes among a large triple-negative breast cancer cohort unselected for family history of breast cancer. I Clin Oncol 2015:33:304-11.

40 Hashizume R, Fukuda M, Maeda I, Nishikawa H, Oyake D, Yabuki Y, Ogata H, Ohta T. The RING heterodimer BRCA1-BARD1 is a ubiquitin ligase inactivated by a breast cancer-derived mutation. J Biol Chem 2001;276:14537-40.
41 Sy SM, Huen MS, Chen J. PALB2 is an integral component of the BRCA complex required for homologous recombination repair. Proc Natl Acad Sci U S A 2009;106:7155-60.

42 Chen CF, Li S, Chen Y, Chen PL, Sharp ZD, Lee WH. The nuclear localization sequences of the BRCA1 protein interact with the importin-alpha subunit of the nuclear transport signal receptor. J Biol Chem 1996;271:32863-8.

43 Park JY, Zhang F, Andreassen PR. PALB2: the hub of a network of tumor suppressors involved in DNA damage responses. Biochim Biophys Acta 2014;1846:263-75.

44 Xia B, Sheng Q, Nakanishi K, Ohashi A, Wu J, Christ N, Liu X, Jasin M, Couch FJ, Livingston DM. Control of BRCA2 cellular and clinical functions by a nuclear partner, PALB2. Mol Cell 2006;22:719-29.

45 Moynahan ME, Jasin M. Mitotic homologous recombination maintains genomic stability and suppresses tumorigenesis. Nat Rev Mol Cell Biol 2010;11:196-207.

46 Seal S, Thompson D, Renwick A, Elliott A, Kelly P, Barfoot R, Chagtai T, Jayatilake H, Ahmed M, Spanova K, North B, McGuffog L, Evans DG, Eccles D, Easton DF, Stratton MR, Rahman N. Breast Cancer Susceptibility Collaboration (UK). Truncating mutations in the Fanconi anemia J gene BRIP1 are low-penetrance breast cancer susceptibility alleles. Nat Genet 2006;38:1239-41.

47 Solyom S, Aressy B, Pylkäs K, Patterson-Fortin J, Hartikainen JM, Kallioniemi A, Kauppila S, Nikkilä J, Kosma VM, Mannermaa A, Greenberg RA, Winqvist R. Breast cancer-associated Abraxas mutation disrupts nuclear localization and DNA damage response functions. Sci Trans/ Med 2012;4:122ra23.

48 Bignell G, Micklem G, Stratton MR, Ashworth A, Wooster R. The BRC repeats are conserved in mammalian BRCA2 proteins. Hum Mol Genet 1997:6:53-8.

49 Chen PL, Chen CF, Chen Y, Xiao J, Sharp ZD, Lee WH. The BRC repeats in BRCA2 are critical for RAD51 binding and resistance to methyl methanesulfonate treatment. Proc Natl Acad Sci U SA 1998;95:5287-92.

50 Yang H, Jeffrey PD, Miller J, Kinnucan E, Sun Y, Thoma NH, Zheng N, Chen PL, Lee WH, Pavletich NP. BRCA2 function in DNA binding and recombination from a BRCA2DSS1-ssDNA structure. Science 2002;297:1837-48.

51 Davies OR, Pellegrini L. Interaction with the BRCA2 C terminus protects RAD51-DNA filaments from disassembly by BRC repeats. Nat Struct Mol Biol 2007;14:680-3.

52 Moynahan ME, Pierce AJ, Jasin M. BRCA2 is required for homology-directed repair of chromosomal breaks. Mol Cell 2001;7:263-72.

53 von Nicolai C, Ehlén Å, Martin C, Zhang X, Carreira A. A second DNA binding site in human BRCA2 promotes homologous recombination. Nat Commun 2016;7:12813.

54 Chapman MS, Verma IM. Transcriptional activation by BRCA1. Nature 1996;382:678-9

55 Xu X, Weaver Z, Linke SP, Li C, Gotay J, Wang XW, Harris CC, Ried T, Deng CX. Centrosome amplification and a defective G2-M cell cycle checkpoint induce genetic instability in BRCA1 exon 11 isoform-deficient cells. Mol Cell 1999;3:389-95.

56 Schlacher K, Wu H, Jasin M. A distinct replication fork protection pathway connects fanconi anemia tumor suppressors to RAD51-BRCA1/2. Cancer Cell 2012;22:106-16.

57 Abbott DW, Thompson ME, Robinson-Benion C, Tomlinson G, Jensen RA, Holt JT. BRCA1 expression restores radiation resistance in BRCA1-defective cance cells through enhancement of transcription-coupled DNA repair. J Biol Chem 1999;274:18808-12.

58 Farmer H, McCabe N, Lord CJ, Tutt AN, Johnson DA, Richardson TB, Santarosa M, Dillon KJ, Hickson I, Knights C, Martin NM, Jackson SP, Smith GC, Ashworth A. Targeting the DNA repair defect in BRCA mutant cells as a therapeutic strategy. Nature 2005;434:917-21

59 Moynahan ME, Chiu JW, Koller BH, Jasin M. Brca1 controls homology-directed DNA repair. Mol Cell 1999;4:511-8.

60 Jhuraney A, Velkova A, Johnson RC, Kessing B, Carvalho RS, Whiley P, Spurdle $A B$, Vreeswijk MP, Caputo SM, Millot GA, Vega A, Coquelle N, Galli A, Eccles D, Blok MJ, Pal T, van der Luijt RB, Santamariña Pena M, Neuhausen SL, Donenberg T, Machackova E, Thomas S, Vallée M, Couch FJ, Tavtigian SV, Glover JN, Carvalho MA, Brody LC, Sharan SK, Monteiro AN; Evidence-based Network for the Interpretation of Germline Mutant Alleles Consortium. BRCA1 circos: a visualisation resource for functional analysis of missense variants. J Med Genet 2015;52:224-30.

61 Bouwman P, van der Gulden H, van der Heijden I, Drost R, Klijn CN, Prasetyanti P, Pieterse M, Wientjens E, Seibler J, Hogervorst FB, Jonkers J. A high-throughput functional complementation assay for classification of BRCA1 missense variants. Cancer Discov 2013;3:1142-55.

62 Monteiro AN, August A, Hanafusa $\mathrm{H}$. Evidence for a transcriptional activation function of BRCA1 C-terminal region. Proc Natl Acad Sci U S A 1996;93:13595-9.

63 Chen L, Nievera CJ, Lee AY, Wu X. Cell cycle-dependent complex formation of BRCA1.CtIP.MRN is important for DNA double-strand break repair. J Biol Chem 2008:283:7713-20.

64 Zhang F, Fan Q, Ren K, Andreassen PR. PALB2 functionally connects the breast cancer susceptibility proteins BRCA1 and BRCA2. Mol Cancer Res 2009;7:1110-8.

65 Sartori AA, Lukas C, Coates J, Mistrik M, Fu S, Bartek J, Baer R, Lukas J, Jackson SP. Human CtIP promotes DNA end resection. Nature 2007:450:509-14.

66 Milner J, Ponder B, Hughes-Davies L, Seltmann M, Kouzarides T. Transcriptional activation functions in BRCA2. Nature 1997;386:772-3

67 Daniels MJ, Wang Y, Lee M, Venkitaraman AR. Abnormal cytokinesis in cells deficient in the breast cancer susceptibility protein BRCA2. Science 2004;306:876-9. 
68 Menzel T, Nähse-Kumpf V, Kousholt AN, Klein DK, Lund-Andersen C, Lees M, Johansen JV, Syljuåsen RG, Sørensen CS. A genetic screen identifies BRCA2 and PALB2 as key regulators of $G 2$ checkpoint maintenance. EMBO Rep 2011;12:705-12.

69 Jensen RB, Carreira A, Kowalczykowski SC. Purified human BRCA2 stimulates RAD51mediated recombination. Nature 2010;467:678-83.

70 Yuan SS, Lee SY, Chen G, Song M, Tomlinson GE, Lee EY. BRCA2 is required for ionizing radiation-induced assembly of Rad51 complex in vivo. Cancer Res 1999;59:3547-51.

71 Biswas K, Das R, Eggington JM, Qiao H, North SL, Stauffer S, Burkett SS, Martin BK, Southon E, Sizemore SC, Pruss D, Bowles KR, Roa BB, Hunter N, Tessarollo L, Wenstrup RJ, Byrd RA, Sharan SK. Functional evaluation of BRCA2 variants mapping to the PALB2-binding and C-terminal DNA-binding domains using a mouse ES cell-based assay. Hum Mol Genet 2012;21:3993-4006.

72 Kuznetsov SG, Liu P, Sharan SK. Mouse embryonic stem cell-based functional assay to evaluate mutations in BRCA2. Nat Med 2008;14:875-81.

73 Wu K, Hinson SR, Ohashi A, Farrugia D, Wendt P, Tavtigian SV, Deffenbaugh A, Goldgar $D$, Couch FJ. Functional evaluation and Cancer risk assessment of BRCA2 unclassified variants. Cancer Res 2005;65:417-26.

74 Ray Chaudhuri A, Callen E, Ding X, Gogola E, Duarte AA, Lee JE, Wong N, Lafarga V, Calvo JA, Panzarino NJ, John S, Day A, Crespo AV, Shen B, Starnes LM, de Ruiter JR, Daniel JA, Konstantinopoulos PA, Cortez D, Cantor SB, Fernandez-Capetillo O, Ge K, Jonkers J, Rottenberg S, Sharan SK, Nussenzweig A. Replication fork stability confers chemoresistance in BRCA-deficient cells. Nature 2016;535:382-7.

75 Spurdle AB, Whiley PJ, Thompson B, Feng B, Healey S, Brown MA, Pettigrew C, Van Asperen CJ, Ausems MG, Kattentidt-Mouravieva AA, van den Ouweland AM, Lindblom A, Pigg MH, Schmutzler RK, Engel C, Meindl A, Caputo S, Sinilnikova OM, Lidereau R, Couch FJ, Guidugli L, Hansen T, Thomassen M, Eccles DM, Tucker K, Benitez J, Domchek SM, Toland AE, Van Rensburg EJ, Wappenschmidt B, Borg A, Vreeswijk MP, Goldgar DE. kConFab; Dutch Belgium UV Consortium; German Consortium of Hereditary Breast and Ovarian Cancer; French COVAR group collaborators; ENIGMA Consortium. BRCA1 R1699Q variant displaying ambiguous functional abrogation confers intermediate breast and ovarian cancer risk. J Med Genet 2012;49:525-32.
76 Abel KJ, Xu J, Yin GY, Lyons RH, Meisler MH, Weber BL. Mouse Brca1: localization sequence analysis and identification of evolutionarily conserved domains. Hum Mol Genet 1995;4:2265-73

77 Connor F, Smith A, Wooster R, Stratton M, Dixon A, Campbell E, Tait TM, Freeman T, Ashworth A, Cloning AA. Cloning, chromosomal mapping and expression pattern of the mouse Brca2 gene. Hum Mol Genet 1997;6:291-300.

78 Drost R, Bouwman P, Rottenberg S, Boon U, Schut E, Klarenbeek S, Klijn C, van der Heijden I, van der Gulden H, Wientjens E, Pieterse M, Catteau A, Green P, Solomon E, Morris JR, Jonkers J. BRCA1 RING function is essential for tumor suppression but dispensable for therapy resistance. Cancer Cell 2011;20:797-809.

79 Spugnesi L, Balia C, Collavoli A, Falaschi E, Quercioli V, Caligo MA, Galli A. Effect of the expression of BRCA2 on spontaneous homologous recombination and DNA damage-induced nuclear foci in Saccharomyces cerevisiae. Mutagenesis 2013;28:187-95

80 Abbott DW, Freeman ML, Holt JT. Double-strand break repair deficiency and radiation sensitivity in BRCA2 mutant cancer cells. J Nat/ Cancer Inst 1998;90:978-85.

81 DelloRusso C, Welcsh PL, Wang W, Garcia RL, King MC, Swisher EM. Functional characterization of a novel BRCA1-null ovarian cancer cell line in response to ionizing radiation. Mol Cancer Res 2007;5:35-45.

82 Sakai W, Swisher EM, Jacquemont C, Chandramohan KV, Couch FJ, Langdon SP, Wurz K, Higgins J, Villegas E, Taniguchi T. Functional restoration of BRCA2 protein by secondary BRCA2 mutations in BRCA2-mutated ovarian carcinoma. Cancer Res 2009;69:6381-6.

83 Tomlinson GE, Chen TT, Stastny VA, Virmani AK, Spillman MA, Tonk V, Blum JL, Schneider NR, Wistuba II, Shay JW, Minna JD, Gazdar AF. Characterization of a breast Cancer cell line derived from a germ-line BRCA1 mutation carrier. Cancer Res 1998:58:3237-42.

84 Woods NT, Baskin R, Golubeva V, Jhuraney A, De-Gregoriis G, Vaclova T, Goldgar DE, Couch FJ, Carvalho MA, Iversen ES, Monteiro ANA. Functional assays provide a robust tool for the clinical annotation of genetic variants of uncertain significance. NPJ Genom Med 2016:1:16001. 